\title{
A. INLEIDING.
}

\section{i. Die Feitlike Toestand.}

Dit is 'n algemene verskynsel dat daar verskillende ,,kerke" bestaan binne die christendom. Die ,kerke" tree dan op as georganiseerde eenhede wat selfstandig bestaan. Elkeen van hulle openbaar sy eie, kenmerkende eienskappe en elkeen van hulle behartig die prediking en die sakramentsbediening.

\section{ii. Die Gronde vir hierdie Feitlike Situasie.}

Die grond vir die afsonderlike bestaan van „kerke” is gewoonlik hoofsaaklik tweërlei van aard. Die eerste grond kan ons die taalverskil en die tweede die leerverskil noem. So bestaan daar in elke land 'n kerk wat die taal van daardie land as voertaal besig. Dit kom egter ook voor dat verskille in die leer veroorsaak dat daar kerke wat dieselfde taal praat, langs mekaar bestaan. Dit kom soms ook voor dat daar ,kerke” langs mekaar bestaan wat dieselfde taal praat en ook nie groot beginselverskille openbaar nie.

iii. Die „kerke" beskou hulleself gewoonlik ook nie as absolute groothede nie. Dit beteken dat die „kerke” (die roomse kerk en die meeste sektes uitgesluit) hulleself nie met uitsluiting van die ander beskou as die alleensaligmakende kerk nie. Gewoonlik beskou hulle hulleself as integrale dele van die ganse christendom ${ }^{1}$. Daarom erken hierdie kerke mekaar se bewys van lidmaatskap en verkondiging as eg en geldig, en word die lidmate oor-en-weer, vanselfsprekend onder sekere voorwaardes ${ }^{2)}$, toegelaat tot die avondmaalsviering. Ook die doop word wedersyds erken wanneer dit in die Naam van die Drie-enige God bedien is deur 'n persoon wat behoorlik daartoe georden is.

\section{B. Die Probleem.}

i. In die jongste tyd het daar op allerlei terreine 'n sterk eenheidsstrewe in die Westerse wereld ontwikkel. Ook die kerk is nie deur die huidige eenheidsgees onaangeroer gelaat nie. Daar word 'n skerp kritiek geoefen op die feitlike toestand van die bestaan van verskillende ",kerke” binne die christendom. Dit moet egter gesê word dat hierdie kritiek hom meer in besonder rig teen die egtheid en geldigheid van die verkondiging deur prediking en sakramentsbediening met die voorwaardes daaraan verbonde binne die ruimte van die bepaalde, afsonderlike „kerke”.

1) Vgl. die Kerkwet van die Ned. Herv. Kerk artikel I.

2) Soos bv. dat 'n lidmaat in sy ",eie" kerk nie onder die tweede of derde trap van die tug verkeer nie. 
En veral is hierdie kritiek baie skerp gemik teen die geldigheid van die avondmaalsviering wat nie sondermeer vir alle "gelowiges" toeganklik is nie.

ii. Ons het reeds opgemerk dat die taal- en leerverskil die bestaansgrond van afsonderlike ,kerke" is. Dit is verder nodig om net daarop te wys dat nóg die taal nóg die leer 'n enkelvoudige verskynsel is. Dit is in albei gevalle komplekse verskynsels.

iii. Ons probleem is dan nou om te probeer vasstel of die afsonderlike avondmaalsvierings op grond van die taal- en leerverskil wel gebillik kan word of nie.

\section{Die Taalaangeleentheid.}

i. Die agtergrond van elke taal ${ }^{3}$.

Elke nasie wat sy eie taal praat, het sy eie psigologiese struktuur kragtens die feit dat hy sy eie land bewoon, sy eie geskiedenis het en gedra word deur sy eie kultuur- en geestesbesit. In die kontak met sy volksgenote en die ander is die eie taal die uitdrukkingsmiddel van die eie van elke nasie. Dit beteken dat die taal nooit as 'n geïsoleerde grootheid beskou kan word nie. Die taal is die verstaansmiddel vir die persoon wat gebore en opgevoed is binne die verband van die nasie wie se taal hy praat. Dit beteken dat by die gebruik van die moedertaal die psigiesgeestelike aard en besit meespreek. Die taal van 'n mens kan dus nie losgemaak word van die agtergrond waaruit daardie mens stam nie.

Daarom gaan dit om oneindig veel meer as net die formele of grammatikale ${ }^{4)}$ aangeleentheid wanneer ons oor die taalverskil praat as grond vir die bestaan en voortbestaan van afsonderlike ,,kerke”. Dit word duidelik uit die situasie in ' $n$ land soos Suid-Afrika.

ii. Die Taalaangeleentheid in Suid-Afrika.

Van Suid-Afrika word dikwels gepraat as 'n ,,veelrassige" land. Dit gee vir ons doel baie meer sin om liewer te praat van 'n ,veeltalige" land. Ons verkies dit omdat daar aan die woord ,ras" 'n party-politieke stigma kleef. Omdat die woord in hierdie partypolitieke konnotasie vir sommige mense ,diskriminasie" spel as sou die een mens as gevolg van sy velkleur meerwaardig wees teenoor die ander, wil ons ons van die gebruik van dié woord weerhou. Dit wil ons ook doen omrede die feit dat ons hier met 'n kerklike gesprek besig is en ons beslis nie wil inlaat op die partypolitieke vlak nie.

Suid-Afrika is 'n land waar daar 'n nasie gegroei het met sy eie taal en alles wat dit impliseer. Suid-Afrika is ook 'n land waar verskillende

3) Vgl. R. D. Coertze, Ontwikkelingstempo binne die Bantoegebiede by Afsonderlike Ontwikkeling, die Hervormde Teologiese Studies, 16e Jaargang, 1960, bls. $163 \mathrm{vg}$.

4) Vgl. verder hieroor, K. Heeroma, Kerk en Taal, Jaarboek voor de Eredienst 1961-62, bls. $6-21$. 
Bantoe-stamme in hulle beweging van Noord na Suid in aanraking gekom het mat die Afrikaner-nasie wat as besliste deel van sy wording en groei in hierdie land, 'n beweging van Suid na Noord gehad het. Sedert 1820 het 'n aansienlike getal Engelstaliges hulle ook in hierdie land gevestig. Tot in die jongste tyd toe het ook nog groter en kleiner groepe anderstalige immigrante die land binnegekom. So het Suid-Afrika ontwikkel tot ' $n$ veeltalige land.

Dit word daagliks ervaar dat enerstaliges saamgroepeer op godsdienstige, sosiale en heel dikwels ook op party-politieke terrein. Dit is heeltemal verstaanbaar en val te verklaar uit die feit dat hulle wat dieselfde taal praat uit 'n gemeenskaplike psigiese eenheid, dieselfde nasie, met 'n gemeenskaplike geestesklimaat, kom. Hierdie mense groepeer saam omdat hulle mekaar nie net grammatikaal verstaan nie, maar ook op grond van hulle gemeenskaplike agtergrond en herkoms mekaar psigies-geestelik begryp ondanks die onderlinge persoonsverskille wat daar mag wees.

iii. Aanpassing.

In hierdie situasie is aanpassing tussen die verskillende taalgroepe gewoonlik 'n lang, meestal 'n moeitevolle en dikwels 'n uitgeslote moontlikheid. Dit val ook wel te verstaan as ons onder volledige aangepastheid verstaan dat 'n lid van een taalgroep die ander taalgroep psigies-geestelik so volkome begryp dat hy tenvolle opgeneem kan word in daardie ander taalgroep, sodat hy homself onvoorwaardelik een kan ag met daardie ander nasie wat die ander taal praat. Dit word geillustreer deur die feit dat die kinders uit die huwelik tussen twee anderstaliges gewoonlik opgevoed word binne die taa'- en kerkverband van slegs één van die ouers.

iv. Die Skriftuurlike Eise.

By hierdie taalsituasie is daar die Bybelse aspekte wat wel deeglik in die oog gehou moet word.

a) Die evangelie kom altyd na mense toe. Dit is so 'n vanselfsprekendheid dat ons eintlik nie daaroor hoef te praat nie.

b) Maar omdat die evangelie tot mense gerig is, moet dit ook by daardie mense tuiskom. Daarom kom die prinsiepe van die verstaanbaarheid ter sprake. Paulus stel hierdie vereiste in I Kor. 14:3 en 4. Die profetiese werk van die kerk moet geskied deur middel van 'n sinvolle woord in 'n verstaanbare taal. Dan word dit verrig tot opbou van die kerk. Hierby aansluitend meen ons uit Hand. 2:4 tot 12 te kan opmaak dat die Heilige Gees, vir die verbreiding van die Evangelie, Hom wil bedien van 'n verstaanbare taal met sin, inhoud en trefkrag vir die hoorders. Dit tenminste is die eis wat Paulus stel in I Kor. 14:9. Dit moet efter goed verstaan word dat die verstaanbaarheid nie die voorwaarde vir die geloof, maar wel die moontlikheid van die geloof daarstel $\left.{ }^{5}\right)$. Die geloof is die gawe van die Heilige Gees wat wel kan, maar blykbaar nie anders wil

5) Vgl. K. Barth, Kirchliche Dogmitil, Bd. I, S. $477 \mathrm{ff}$. 
$\varepsilon s$ Hom by die stigting en versterking van die geloof van 'n verstaanbare taal te bedien nit $^{6}$.

Hierby het die reformatore angesluit. Bekend is die feit dat een van Luther se groot take die vertaling van die Bybel in die volkstaal was. Bekend is ook die bemoeienis wat hy gemaak het met die erediens in die taal van die volk. Trouens die liturgiese hervorming van die reformasie het as grondslag gehad die eis tot verstaanbaarheid. Daarom is daar weggedoen met die stille misse en latyn as kerktaal by die erediens. En dit verbaas gladnie dat die eis tot verstaantaarheid op reformatoriese erf altyd ernstig geneem is nie. Dit het gekom omdat die $r$ formasie, teneinde te voldoen aan die eis van die Bytbel dat Gods Woord gehoor moet word, die prediking as sinvolle, verstaanbare woord weer in ere herstel het. Daarom het die taalverskil in die kerk van die kerkhervorming terwille van die verkondiging dan ook altyd besondere maatreëls nodig gemaak.

c) Die evangelie eis die hele mens op. Hierby hoef ons eintlik net te verwys na Matth. 22:37. Nogtans is dit goed om tog weer daarop te wys dat die evangelie nooit in 'n lugleegte verkondig word nie, maar altyd aan die adres van mense gerig is. Hierdie mense is mense wat op 'n bepaalde plek, in ' $n$ bepaalde tyd en onder bepaalde omstandighede lewe. Dit wil sê hierdie mense behoort tot 'n bepaalde nasie wie se taal hulle praat en verstaan. Die verkondiging wil altyd sulke mense in die totaliteit van hulle bestaan aanspreek. Daarom bedien die evangelie hom by die kerklike verkondiging aan mense van die taal van daardie mense. Omdat die verstaan van die eie taal nie net ' $n$ redelike aksie is nie, maar 'n handeling van die mens in die totaliteit van sy menswees en omdat die evangelie die mens so as redelike, sedelike en emosionele wese wil ofeis, gebruik rlie verkondiging die volkstaal van elke mens.

\section{v. Die Taalverskil en Afsonderlike "kerke”.}

Wanneer die taalverskil as bestaansgrond van 'n afsonderlike, kerklike crganisasie gesien word in die lig van hierdie Bybelse eise, dan kan ons dit so saamvat: Wanneer die evangelie ons tot geloof in God aanspreek, dan laat dit nie die spesifieke lewenssituasie waarin ons verkeer, ophou om te bestaan nie ${ }^{7}$. Dit is egter só dat ons nie weg van ons wêreld en ons menslike omgrensinge af glo nie, maar in ons wêreld en menslike omgrensinge moet glo terwille van die wêreld. „Want so lief het God die wêreld gehad ..." "s).

Dat hierdie kosmos, die bewoonde wêreld, verskillende tale en nasies insluit, kan nie ontken word nie. Al wat egter hieruit af te lei is, is beslis nie dat die taalverskil bloot geïgnoreer kan of moet word nie, maar wel dit: Die kerk het 'n dubbele verantuoordelikheid. Die kerk moet naamlik

9) Vgl. Hand. 2: 37-41.

?) Otto Weber, Grundlagen der Dogmatik, S. 14.

8) Joh. 3: 16 . 
toesien dat die evangelie aan elke ander nasie in sy eie taal verkondig word en tweedens dat die kerk sondermeer verantwoordelik is vir die nasie van wie se taal die kerk hom bedien op grond van die feit dat die kerk onder daardie nasie bestaan en binne sy landsgrense arbei.

Samevattend kan ons sê: Die taalverskil stig nie aparte „kerke" nie. Ons kan wel sê dat die Heilige Gees Hom in en deur die kerk van verskillende tale bedien vir die verkondiging van die evangelie.

\section{Die Taalverskil en die Avondmaalsviering.}

\section{i. Die Avondmaal is Verkondiging.}

Die Avondmaal is verkondigingsgestalte wat bedien word aan hulle wat reeds openbare belydenis van geloof afgelê het. Volgens I Kor. 11:26 is die bediening en viering van die avondmaal 'n ,verkondiging" van die dood van die Here Jesus Christus totdat Hy kom. Daarom gaan dit by die Avondmaal om die stigting en versterking van die geloof ${ }^{9}$. Dit beteken dat die avondmaal 'n kenmiddel is waardeur Jesus Christus Homself tot geloof aan sy gemeente te kenne gee.

ii. Die Verstaanbaarheid en die Avondmaal.

By die instelling van die heilige nagmaal het Jesus Christus self die verstaanbare woord verbind aan die teken. Daarom wil ons hierdie sakrament omskrywe as woord plus teken. En wanneer een van hierdie momente verval dan het ons dus nie meer die sakrament soos Jesus Christus dit ingestel het nie.

Die woord plus teken waaruit die avondmaalsakrament saamgestel is, is die verklaringswoord van die teken wat deur die teken self bevestig word ${ }^{10}$. Die verklaringswoord is sinloos as die teken nie daarop volg nie. Netso is die uiterlike teken sonder betekenis as die verklarinsgwoord nie daaraan voorafgaan nie. Daar is 'n onlosmaaklike verband tussen die instellingswoorde en die brood en wyn by die nagmaalsviering. Dit beteken dat die avondmaal nie gevier kan word met brood en wyn alleen en sonder die instellingswoord of verklaringswoord nie. So kan die avondmaal ook nie gevier word met die verklaringswoord alleen en sonder die uiterlike tekens nie. Met ander woorde die Here Jesus Christus gee Homself tot geloof te kenne aan sy gemeente slegs wanneer woord en teken in hulle onoplosbare samehang saamgaan.

As nou nader omskrywe word wat bedoel word met die stelling dat Jesus Christus self die verstaanbare woord verbind het aan die sakramentsteken dan kry ons tegelyk ook meer lig op die onderhawige probleem. Die dissipelkring was Arameessprekend en die Here het Aramees gepraat by die instelling. Die instellingswoord sou by hulle verbygegaan

9) Vgl. die Kort Begrip, Vraag en Antwoord 48-50.

10) Matt. 26:26-27; Mk. 14:22-23; Lk. 22: 19-20... 
het as hulle Aramees nie verstaan het in die sin waarin ons verstaan hierbo omskrywe het as 'n redelike, sedelike en emosionele begryp nie. Hulle sou nie daarby in die totaliteit van hulle menswees aangegryp gewees het nie as Aramees nie hulle taal was nie.

Dit kan enigermate geillustreer word as ons net wys op die verskil in begrip van die instellingswoorde wat na die vertalings daarvan in die Grieks van die Nuwe Testament gevolg het. So word die instellingswoorde deur die roomskatolieke, Lutherane en Calviniste onderling heeltemal verskillend verstaan terwyl daar tog geen Bybelse getuienis is dat dit met die dissipelkring by die instellingsgeleentheid die geval was nie. En juis om hierdie rede is dit absoluut noodsaaklik dat die kerk in sy verkondiging eerstens moet seker maak dat die bedoeling van die Bybelwoord soos vervat in die oorspronklike tale heeltemal reg begryp word en tweedens moet die kerk seker maak dat hy die verkondigingstaal gebruik wat deur sy hoorders die beste verstaan word, sodat die gevaar van die misverstaan van die oorspronklike bedoeling van die Bybelwoord tot 'n besliste minimum beperk kan word.

Met die verstaanbare woord by die teken waaruit die sakrament bestaan, bedoel ons dat dit ook by die sakramentsbediening as gestalte van die verkondiging om meer as net ' $n$ verstandelike verstaan moet gaan. Die avondmaalsbediening mik op die versterking van die geloof waarby die gelowige in die totaliteit van sy bestaan aangeraak is en wil nie slegs één menslike fakulteit, nl. die verstand, raak nie. Die mens kan met sy verstand verstaan en tog nog toeskouer bly ten opsigte van daardie aangeleentheid. Maar wanneer hy glo dan kan hy nie toeskouer wees nie maar dan is hy deelnemer, omdat hy glo.

\section{iii. Die Evangelie eis die hele mens op.}

Wanneer ons die sakramentsbediening prinsipieel verstaan as verkondiging en nie in die eerste instansie as die aanduiding van 'n menslike toestand sien nie, dan spreek dit eintlik vanself dat ook die sakrament aan elke mens in sy eie taal bedien moet word.

Dié feit kan op die volgende wyse nog nader verduidelik word. Hier moet ons net eers enkele van ons stellings saamvat.

a) Die avondmaal stig gemeenskap wanneer dit bedien word volgens die instelling van Christus, b) Die bediening volgens die instelling van Christus beteken dat die sakrament moet bestaan uit twee momente nl. die verklarende woord plus die uiterlike teken. c) Die gemeenskapstigting deur nagmaalbediening geskied dus deur woord plus teken.

Wanneer mens nou hierdie stellings aanlê dan word die gebeurtenisse in die Kongo na die ,,selfstandigwording" van dié gebied, vir ons van illustratiewe waarde. Bekend is die roomse opheffing van die verband tussen verklaringswoord en teken by die avondmaalssakrament. Verder is dit ook bekend dat waar daar nog sprake is van die woord by die teken, 
daar is dit nie die verklaringswoord wat ter sprake kom nie, maar wel die konsekrasie-formule in 'n taal (Latyn) wat vir die Kongolese onbegryplik was. En al was daar in die Kongo dan ook die daaglikse misse e.d.m. is daar tog nie werklik gemeenskap gestig nie. Dit word baie duidelik uit die geweldpleging teen priesters en nonne en die vernietiging van kloosters.

Ons meen dus te verklaar dat ook in gevalle waar die teken verbind word aan 'n taal wat nie tenvolle begryp word soos die eie taal nie, daar ook nie werklik gemeenskap gestig word nie. Daarom wil ons dit ook stel dat om verskillend-taliges ongeag die taalfaktor te wil saambring aan een nagmaalstafel nie aanvaarbaar is nie. Dit is nie aanvaarbaar nie omrede die feit dat dit prinsipieel gesien daarop neerkom dat vir 'n hele aantal van die vierders die avondmaal nie bedien word volgens die instelling van Christus nie. Vir sommige van die vierders beten so 'n viering noodwendiger wyse 'n opheffing van die verband tussen die verklaringsw'oord en die teken omdat die avondmaal bedien word deur 'n medium wat vir hulle nie tenvolle verstaanbaar is nie en gevolglik is hulle uitgesluit uit die volle gemeenskap met die ander.

\section{E. Uitsonderingsgevalle.}

Daar moet nog daarop gewys word dat daar wel uitsondering is ook sover dit die taalfaktor aangaan. Daar is $\mathrm{nl}$. baie goeie taalkundiges wat wel tot op baie groot hoogte die evangeliebediening en sakramentsviering in 'n ander taal sal kan begryp. Maar die Here God laat sy Woord beslis nie net aan taalkundiges verkondig nie maar aan die ganse mensdom. En daar is beslis baie meer mense wat net hulle taal ken as die enkelinge wat beslis as taalkundiges kan kwalifiseer. Sommige mense praat byvoorbeeld graag Frans of Engels terwyl dit in werklikheid niks anders is as die nabootsing van die klanke van Frans en Engels nie.

Wanneer ons die uitsonderings ook van toepassing maak op die kerklike situasie in Suid-Afrika en veral op 'n inter-kommunie tussen blank en nie-blank sal ons seker almal bereid wees om toe te gee dat enkele nie-blankes wel die verloop van die erediens in Afrikaans sal kan volg en dat daar miskien wel werklike ,avondmaalsgemeenskap" tot stand sal kan kom. Maar daarom kan die enkele nie-blankes tog nie opgeneem word in Afrikaanssprekende gemeentes nie. Die volgende oorwegings dien hierby in aanmerking geneem te word:

i. So 'n verdeling van die nie-blankes in ,,geleerdes" en ,,ongeleerdes" as grond vir opname in die Afrikaanse gemeentes steun op geen Bybelse grond nie. Trouens dit is die geloof $\mathrm{en}$ nie die geleerdheid wat kerklike oorweging verdien en by kerklike gemeenskapheid wat kerklike oorweging verdien en by kerklike gemeensskap ter sprake kom.

ii. Die geleerde nie-blanke sal daarop gewys moet word dat mens nie weg van jou eie lewenssituasie af glo nie, maar juis daarheen. 
iii. Omdat die kerk 'n besondere verantwoordelikheid het teenoor die volk wie se taal hy praat, sal die geleerde nie-blankes as hulle gelowiges is, gewys moet word op die onherroeplike verantwoordelikheid wat hulle teenoor hulle eie mense het ten opsigte van die evangelie.

iv. Deur 'n verdeling geleerd-ongeleerd an te bring onder die geledere van die nie-blanke sal die evangelie nie verbrei nie, maar eerder geskaad word, omdat die evangelie en veral die avondmaalsviering dan baie maklik in die gedagtes van die ongeleerdes gebrandmerk kan staan as die spel van geleerde snobiste wat in hulle vlug na die ander toe hulle eie mense versaak.

v. Met die oog op die taalverskil sal dit beslis veel eerliker wees as blanke en nie-blanke gemeentes selfstandig en gelykwaardig langs mekaar staan, sonder dat die een ondergeskik is aan die ander terwyl hulle mekaar adviseer en vir mekaar voorbidding doen.

\section{F. Konklusie.}

Die taalfaktor maak dit in die lig van voorgaande betoog noodsaaklik dat aan elke mens in sy eie taal die evangelie verkondig en die sakramente bedien moet word. Daarom kan ons geen beswaar hê teen die egtheid en die geldigheid van die verkondiging aan elke nasie in sy eie taal nie en gevolglik ook nie teen die bestaan van afsonderlike ,,kerke" vir die verskillende taalgroepe nie.

\section{G. Die Leerverskil.}

Wanneer ons hier praat van die leerverskil as grond vir die bestaan van afsonderlike kerklike organisasie, dan wil ons eerstens daarop wys dat ons met leerverskil ook 'n komplekse aangeleentheid bedoel $\mathrm{nl}$. leer én aanverwante sake.

By die leer van die kerk gaan dit om die vraag na wat waar en reg is volgens die Skrif. Daarom is die leer 'n belangrike aangeleentheid vir die kerk ${ }^{11}$. Die kerk moet trouens altyd sy woord en daad gaan toets aan die Skrif as bron en norm van wat waar en reg is vir die kerk. Daarom kan ons sê dat die leerkwessie 'n saak van lewensbelang is vir die kerk.

In hierdie sin stel die leer vir die kerk sy gids en grens. As gids wil die leer die kerk lei in die regte verstaan en verkondiging van die Bybelse waarheid. As grensaanduiding wil die leer vir die kerk in sy verkondiging perke stel. Dit wil sê dat die leer as gids en grens die kerk alleen wil hou aan die getuienis van die Skrif as die skriftelike neerslag van die getuienis van profete en apostels aangaande die Woord van God. Die kerk kan alleen leef uit die hoor en die verkondiging van die Woord van God.

11) Vgl. I Tim. 6:3-4a. 
Trouens die kerk is alleen kerk in die akte van die hoor en die verkondiging ran die Woord. Terwyl die leer wil sorg vir die regte hoor en verkondiging van die Woord, wil dit dan ook sorg vir die voortbestaan van die kerk.

In hierdie verband moet vervolgens gewys word op die positiewe en negatiewe aard van die leer van die kerk. Die positiewe aspek het ons reeds aangetoon deur te wys op die funksie van gids en grens wat deur die leer vervul word. Die negatiewe aspek is nl. dat wanneer dit die regte andui dit ook antiteties staan teenoor die dwaling en die verkeerde.

Dit is juis hierdie feit wat daarvoor verantwoordelik was dat daar 'n kerkhervorming tot stand gekom het. Die bewyse daarvoor vind ons byvoorbeeld in die feit dat Luther en Calvyn om maar die twee vernaamstes te noem, se teologiese arbeid ' $n$ beslis leerstellige karakter dra. Trouens die hele reformasie dra die karakter van die soek na en aantoon van dit wat Bybels waar en reg is teenoor die dwaling en die verkeerde. Daarom dra die leer van die Kerk altyd die karakter van geloofsbelydenis waarvan die inhoud daardie dinge is wat die kerk as Gods Woord gehoor het op grond van die getuienis van die Bybel, sodat die kerk niks anders nie, maar juis daardie leer moet bely as waar en reg. Die leer van die kerk is geen luukse of spel nie maar noodsaaklikheid terwille van die regte verkondiging.

Samevattend kan ons dus sê dat die leerverskil as grond vir selfstandige, afsonderlike organisatoriese kerklike eenhede 'n swaarwegende grond is omdat die basis van hierdie grond die vraag is na wat Bybels waar en reg is.

\section{H. Die Leerverskil en Avondmaalsgemeenskap.}

Ons het reeds daarop gewy's dat die avondmaal 'n binne-kerklike gestalte van die verkondiging is ${ }^{12}$. Ons het ook reeds daarop gewys dat die leer gemoeid is met die waarheid wat reg verkondig moet word. Hierdie twee stellings se uitwerking is eintlik dat daar 'n nou verband is tussen die leer en die avondmaalsbediening van die kerk. Hierdie verband word tot uitdrukking gebring deur die woorde,$\ldots$ soos Christus dit ingestel het . . ."13).

In die lig hiervan moet ons tot die slotsom kom dat alleen by die regte bediening van die avondmaal daar sprake kan wees van die regte verkondiging van die Woord. Daarom is die formulier van die avondmaal eintlik 'n didaktiese of leerstellige geskrif. Die formulier maak dan ook duidelik dat die regte viering van die avondmaal inhoudelik bepaald is deur die evangelie soos dit vir ons deur die Skrif betuig is.

Daarom word duidelik onderskei tussen die verskillende avondmaalslere. Die roomse leer dat brood en wyn deur die konsekrasie die liggaam

12) I Kor. $11: 26$.

13) Nederlandse Geloofsbelydenis, art, 29. Vgl. Ef. $2: 20$. 
en bloed van Jesus Christus word, word byvoorbeeld in die calvinistiese kringe verwerp as verkeerd. Die konsekwensie van hierdie leer is dat die liggaam en bloed van die Here by die avondmaal met die mond ge-eet word. Dit word op Bybelse gronde verwerp as verkeerd. Teenoor 'n eet en drink met die mond verklaar die Nederlandse Geloofsbelydenis artikel 35 dat die ontvangs van die ware liggaam en bloed van Jesus Christus deur die geloof „wat die hand en die mond van ons siel is" "tot ons geestelike lewe" is.

By die onderskeiding tussen waar en reg gaan dit eintlik om die onlosmaaklike verband tussen woord en teken. Dit beteken dat die vraag na wat eintlik geleer word deur die avondmaalsviering wel van belang is. In hierdie verband moet Paulus se verbod op 'n sinkretistiese verbastering van die avondmaal in aanmerking geneem word ${ }^{14}$. Ten opsigte van die avondmaalsviering staan die saak eintlik sb dat die leerkwessie van beslissende ketekenis is. Daarom kan die vraag na die leer nie as onverskillig of onbelangrik tersyde gestel word nie. Omdat die regte bediening van die nagmaal ook 'n saak is van die regte leer is soiets soos 'n inter-konfessionele of onkonfessionele nagmaalsviering 'n bedenklike aangeleentheid. Waar daar tog gepoog word om nagmaal te vier met verbygaan of verontagsaming van die leer, daar is dus eintlik nie sprake van nagmaalsviering en gevolglik ook nie van nagmaalsgemeenskap nie ${ }^{15}$.

\section{Misverstande by interkonfessionele Kommunie.}

Omdat dit in die konfessie gaan om wat waar en reg is volgens die Skrif daarom is daar nie sprake van gemeenskaplike viering van mense van verskillende konfessies nie. Dit kan wel om die volgende redes gesê word.

i. Dit is onmoontlik om ' $n$ werklike eenheid daar te stel as daar nie ook eenheid van geloof is nie. By so 'n interkommunie sal die skeiding aangebring word deur die verskillende konfessies waardeur die geloof van die verskillende vierders uitgedruk word. Dit is tenminste onvermydelik as elkeen van die vierders sy geloof werklik toegedaan is. Daarom kan die leer net eenvoudig nie verbygegaan word nie. Dit beweer ook prof. K. Barth na aanleiding van vraag en antwoord 80 van die Heidelbergse Kategismus ${ }^{16}$. Hy beweer dat geen Una Sancta-beweging hierdie leerverskil kan oorbrug of uitskakel nie.

iij Wanneer ons in anmerking neem dat die Heilige Gees deur die prediking en die sakramente juis ons geloof só in ons harte werk sodat ons dit nie willekeurig nie, maar eenvoudig as 'n kan-nieanders in ons belydenis tot uitdrukking bring, dan val dit te verstaan dat ' $n$ interkonfessionele avondmaalsviering onmoontlik

\footnotetext{
16) I Kor. 10: 21 .

16) I Kor. 10: 16-17.

30) K. Barth, Die Christeliche Lehre nach dem Heidelberger Katechismus, S. 105.
} 
nie gemeenskap kan stig nie. Die Heilige Gees werk tog nie teen Homself nie. Dit is tog eintlik nie moontlik dat die Heilige Gees aan dieselfde tafel die een vierder in die roomse geloof en die ander in die protestantse geloof sal versterk terwyl hierdie twee lere teenoor mekaar staan nie.

iii. Dit is onmoontlik om die leer tersyde te stel. Dit word duidelik as ons ons geloof bely as afkomstig van die Heilige Gees deur die verkondiging. Ons as mense het nie beskikkingsreg oor die werk van die Heilige Gees nie en beskik ook nie oor die moontlikheid om wat die Heilige Gees gedoen het, te neutraliseer nie. Met ander woorde as ons ons geloof werklik toegedaan is, dit wil sê as ons deur die Heilige Gees daar gebring is waar alle teenspreek eindig, sodat ons nie anders kan as om ons neer te lê by die gesag van Gods Woord nie, dan het ons ook by die punt gekom waar die leer fungeer. Die leer is geen luukse nie maar onvermydelike noodsaaklikheid om so noukeurig as wat maar moontlik is na te sê wat as Gods Woord gehoor is. Dit is vir 'n gelowige dus netso onmoontlik om die leer tersyde te stel as wat dit is om die bloedverwantskap met sy eie moeder te ontken. Wanneer die leer só verstaan word, dan is tersydestelling van die leer as onbelangrik of onnodig niks anders as ongehoorsaamheid aan die getuienis van die Gees nie. ${ }^{17)}$

iv. Die oorbrugging van leerverskille geskied nooit deur 'n woordlose interkommunie nie. Die leerverskille moet eers deur gesprek verwyder word voordat werklike geloofsgemeenskap aan die avondmaalstafel sal kan plaasvind. Dit is so omdat daar nie sprake van geloofsgemeenskap is as daar nie sprake is van 'n onvoorwaardelike neerlê by die objektiewe waarheid van Gods Woord nie. Wanneer mense dus wil saam nagmaal vier ongeag die leerverskille in die hoop dat 'n eenheid gedemonstreer en ervaar sal word, dan is so 'n viering niks anders as 'n herlewing van die ou piëtsime waar die subjektiewe ervaring hoër aangeslaan word as die objektiewe waarheid van Gods Woord en die geloof gereduseer word tot die allerprivaatste emosie van elke afsonderlike „deelnemer". Dan is die geloof nie meer gawe van God nie, maar menslike prestasie. Dan is daar ook nie meer sprake van 'n nagmaalsviering volgens die instelling van Christus nie want die avondmaal is gerig op die vermeerdering van geloof en is beslis nie middel tot menslike prestasie nie.

\section{J. Konklusie.}

Die leerverskil maak 'n nagmaalsviering van alle „,gelowiges” ongeag

17) Dit is ons baie ernstige kritiek op J. H. van Beusekom, Enkele Opmerkingen over oecumemische Avondmaalsviering, Jaarboek voor de Eredienst 1961-62, bls 114 punt (c) waar hy beweer dat die avondmaalsleer gemeenskaplike avondmaals. vieringe nie mag verhinder nie. 
die leer wat hulle aanhang, onmoontlik en ook 'n neutrale verkondiging waarin die leer nie geld as gids en grens nie. Daarom kan ons die aparte "kerke" op grond van die leerverskil nie as strydig met die evangelie beskou nie. Dog daarby moet dadelik gesê word, dat die leerverskil nie 'n absolute grootheid beskou kan word nie. En eukumenisiteit sal dus nie probeer om die leerverskil te ignoreer nie, maar sal moet probeer om deur middel van 'n Bybelse gesprek die leerverskil uit die weg te ruim. Dit sal veral ook moet geskied in gevalle waar kerke wat geen prinsipiële leerverskille het nie en dieselfde taal praat, langs mekaar bestaan.

Wat betref die sakrament: As die kerk dit suiwer wil bewaar, dan sal die kerk sowel die taal- as die leerverskille moet eerbiedig. 